\title{
The Effectiveness of a Project Manager for Risk Management in a Career Education Project
}

\author{
Kazutsune Moriya \\ Graduate School of Media and Governance, Keio University, Tokyo, Japan \\ Email: kazuzzen@sfc.keio.ac.jp
}

Received 25 February 2014; revised 25 March 2014; accepted 1 April 2014

Copyright (C) 2014 by author and Scientific Research Publishing Inc.

This work is licensed under the Creative Commons Attribution International License (CC BY).

http://creativecommons.org/licenses/by/4.0/

(c) (i) Open Access

\begin{abstract}
As a framework for the effort to develop perspectives for work and promote autonomous career development among young people, schools at all levels-from elementary schools to universities-are introducing and conducting career education. One result of these efforts has been that career education, which is supposed to be conducted systematically while maintaining a certain level of quality, is currently not functioning well. More specifically, the wide range of career education curricula and the fact that the method of execution is completely up to each teacher has led to inconsistent quality and a range of risks. To help address this, and given that career education itself constitutes a project towards achieving the education goals, this paper argues that using a project manager in career education-a role that has been entirely left up to each teacher to fill or provide-is effective in managing the risks involved in career education projects and proactively providing countermeasures to offset these risks.
\end{abstract}

\section{Keywords}

Risk Management, Risk Mitigation, Proactive Risk Countermeasures, Career Education

\section{Introduction}

Although project cycle management was initially popularized as a management method primarily in the IT industry, it has come to be used in various fields in recent years, from publishing to automobile manufacturing to collaboration across industries. Yet, in the field of education, the project management method has not become common except as a course subject.

This paper will focus on the Japanese context and will discuss whether and in what ways the project man- 
agement method is applicable and effective in the career education programs that schools are actively beginning to provide, particularly in terms of risk management, assisting to identify positive and negative risks.

\section{Career Education and Project Management}

According to the Central Council for Education of the Japanese Ministry of Education, Culture, Sports, Science and Technology (MEXT), career education is "an education that promotes career development through training skills and attitudes that become a required foundation for each individual to become socially and vocationally independent” (Central Council for Education, 2011). Originally, "career education” was a term that Sidney Marland, Jr., Director of the Office of Education under the US Federal Security Agency, began using in 1971 to refer to a new model or philosophy of education related to career guidance for students. In Japan, schools began incorporating this philosophy after it was proposed by the Central Council for Education as "an education that aims to facilitate a smooth transition from school education to vocational life by teaching students desirable perspectives for work, knowledge and skills related to [their] occupation, and skills and attitudes necessary to understand [their] own individuality and choose a career path autonomously" (Central Council for Education, 1999). According to a report released by the Council of Collaborators Conducting Comprehensive Research on Career Education Promotion (2004) within MEXT, career education, which aims to launch "a broader range of activities than traditional career guidance" and to "teach the meaning of work and the purpose of acquiring technical knowledge and skills by questioning the conventional vocational education that focused on teaching technical knowledge and skills," is provided as way to develop perspectives on work that are appropriate for the developmental stage of the student, over the course of education from elementary school to university. Specific means to implement this kind of career education include internships, lectures by working individuals, interviews with working individuals, visits to companies, tours of factories, and so forth. Roughly speaking, any effort to create an opportunity for youth to think about their future can be considered career education.

Among these approaches, the most typical kind of career education is an internship, which functions as a way for students to experience a workplace and gain experience in work related to their own major or future career while still in school, arranged through cooperation between the school and the company or organization at which the student will intern. The benefits of an internship include the fact that the company can promote itself to students, while the student can evaluate their own aptitude for employment in that sector, and the school can show the community that it is fulfilling the role of an educational institution.

So far, the way career education programs, including internships, have been implemented and operated has varied depending on the teacher's experience and skill; that is, career education programs have never been systematically managed.

Project management has great potential to be of help in operating and managing career education because, as can be seen in Table 1, career education meets the requirements to be considered a project: it defines an implementation period given the goal of developing perspectives for work, and it is accomplished by multiple individuals with a certain budget. Therefore, introducing the project management methods into career education, in particular introducing and applying the concept of risk management, will probably be effective since it deals with analyzing the risks and helps in taken precautionary steps to reduce future risks.

\section{Challenges in Implementing Career Education Projects}

The implementation of career education is required in MEXT's official course curriculum guidelines for elementary school, junior high school, and high school. For example, the general rules section of the guidelines for high school states that high schools are to "promote career education by providing planned and systematic career guidance," stressing that career education activities need to be included when drawing up a school curriculum. The challenge in implementing career education in this context is that it is left entirely up to the educators in the field to determine exactly what type of programs to develop and what actual activities to carry out. There is a compelling argument that educational methods and policy should indeed be left to teachers, in that educational activities should be directed according to various criteria such as students' academic abilities and developmental stage. However, we can easily see that career education will not function effectively as a project if teachers who are intended to be responsible do not recognize career education's "projecthood" and who do not implement it specifically as an educational goal and just consider it as a class or have difficulty in managing and operating the program. Career education is worthy of being called a project, and as long as it is a project, the need for a project 
Table 1. Common ground between project management and career education programs.

\begin{tabular}{|c|c|c|}
\hline & Project management & Career education program \\
\hline 1 & There is a goal & It teaches students the meaning of work \\
\hline 2 & There is a defined starting point and ending point & The period ranges from one week to several months \\
\hline 3 & Activities are budget based & Companies implement the program with a certain budget \\
\hline 4 & Members temporarily cooperate & Once the program is completed, students return to normal classes \\
\hline 5 & Activities are performed by multiple individuals & $\begin{array}{l}\text { It is collaborative work involving multiple individuals } \\
\text { from the company side }\end{array}$ \\
\hline
\end{tabular}

manager is not a matter that can be ignored. However, the reality is that it is very difficult from the standpoint of time constraints to expect teachers who are already busy with their main job of teaching to manage and operate an additional extracurricular career education program. Kitagami and Takagi (2007) as well as Shintani (2012) point out that the sense of busyness at work is overwhelming among teachers in Japan. Although this sense of busyness among teachers may vary by the type of school they teach at, a study conducted by the Benesse Educational Research and Development Center indicates that Japanese teachers' work hours exceed 11 hours per day on average (Benesse Educational Research and Development Center, 2008). When executing a career education project, the other commitments and time-stretched work conditions of teachers who should be serving as project managers, holding the key to success, are a major problem. Another problem is the fact that teachers are not necessarily capable of effectively managing a program on their own from a project standpoint. For example, when carrying out an internship program as career education, the following are examples of situations in which co-management between three parties —-the student, the teacher, and the company-becomes important.

1) Because career education requires cooperation among many stakeholders, intermediation and coordination among them become essential; this can be achieved more effectively with an individual dedicated to the purpose.

2) Because the program must be conducted on an ongoing basis in order to gain the desired educational benefits, the appointment of an individual to be involved on a long-term basis as a mediator is important.

3) The teacher may not have the background to manage risk effectively in a project, while a trained manager will.

Items 1) and 2) above can be regarded as expected risks inherent to career education as a project. In contrast, 3) requires the consideration of unexpected risks in advance. In other words, this is a risk management issue that needs to be considered by a person who knows much about a project, such as a project manager.

Career education projects are often affected when government agencies make policy changes or schools revise their plans. Consequently, for the projects to run smoothly, administrators must remain constantly up to date on such information and be able to respond preemptively. The importance of the project manager in this sense cannot be stressed enough. In addition, one of the goals of career education is to develop participants' attitudes toward their job—a goal that cannot be achieved simply by requiring them to complete one or two specialized courses. For this reason, effective career education requires cooperation between many different departments. Coordination between instructors, as well as coordination between the faculty and departments, is therefore critical to the success of career education projects. Here, too, the project manager has an important role to play in mediating between the various interests involved.

\section{Career Education Projects}

Defined as "an education that promotes career development through training skills and attitudes that become a required foundation for each individual to become socially and vocationally independent" (Central Council for Education, 2011), career education requires teachers to 1) understand each student, 2) have the educational capabilities to foster skills and attitudes that students will need in the future, and 3) have the ability to assess each student's inner developmental stage. These capabilities - to understand, educate, and figure out —are not acquired from preexisting knowledge or know-how; instead, they are developed through communication between teachers and students, in which the teacher faces the students with sincerity and keeps questioning them regarding what they are thinking and seeking now. According to Hayashi, who developed the training model, the effect 
of a teacher's communication skill on students is quite large (Hayashi, 2011); therefore, training models aiming to improve communication skills have been developed.

The question of communication skills naturally leads to the issue of communication management in the project operation. In other words, regardless of the status of the project manager (as a teacher or a third party), that individual is required to have adequate communication with all involved parties, including the school, company, and student, identify what each party seeks, and properly evaluate the situation. Furthermore, the individual must make decisions that respect each stakeholder's position while also assessing their actions. While the manager can assert his/her own opinion, he/she should not be allowed to make arbitrary decisions.

\subsection{Risk Management}

Risk management in a career education project should be conducted in a way that closely considers the progress and characteristics of the individual project. This is because career education projects such as internships are personalized projects in which each student, with his or her individual personality and skills, experiences a different type of work under a different form of employment at a company in a different industry, and it is difficult to fully understand the specific risks in each case in advance. Therefore, it is most important to respond to risk in career education immediately before it occurs or immediately after the risk emerges, that is, in tandem with the flow of the project, as in Figure 1.

Although in practice most risk management measures in career education will inevitably be done after the fact, it is nevertheless essential to try to identify risks that can be expected and anticipate all possible situations and issues. The following are some examples.

1) Background of the teacher (e.g., whether he/she has ever been involved in career education and has an understanding of career education, whether he/she is familiar with project management and understands the concept of risk management, etc.).

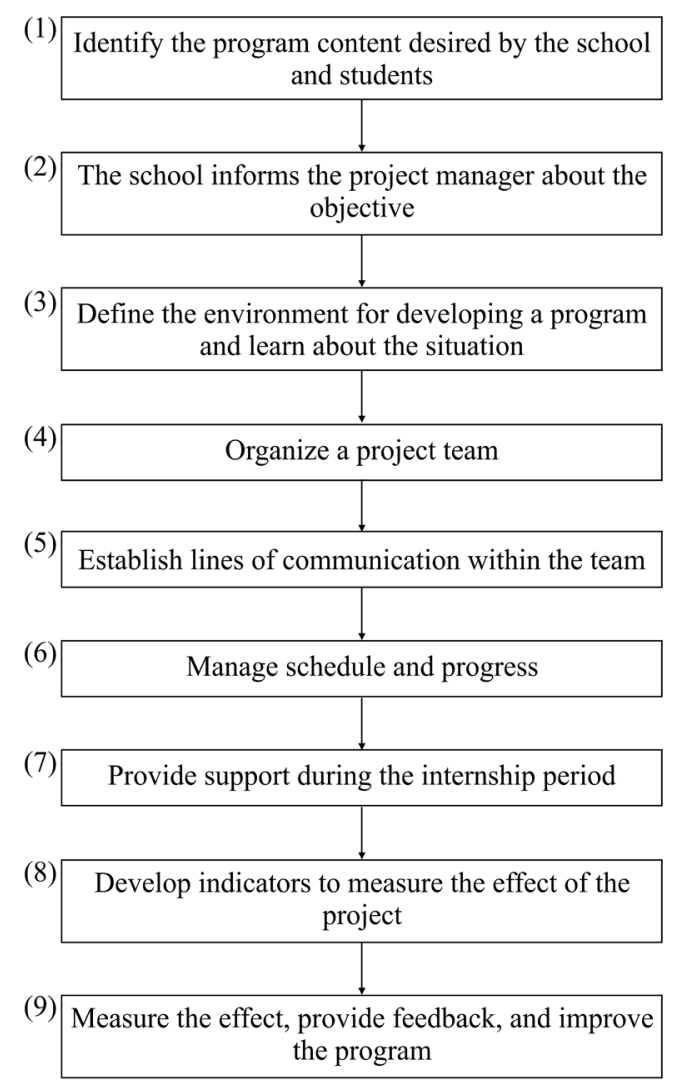

Figure 1. The flow of a managed career education project. 
2) Environment for program implementation (timing and implementation period, number of hours, understanding of the environment at the school, etc.).

3) Information on the school (reason for interest in career education, division in charge of career education, rough understanding of school performance and culture, etc.).

4) Goal-setting for the project (establishing what the project is intended to achieve, determining how to organize the program—how much time will be spent at school and how much in internship, etc.).

Development and preparation of teaching materials (identifying the learning materials that the students will use and what will be provided by the school and/or the student, pricing and procuring materials, determining whether these materials are effective for the student's career development and autonomy, conducting a costbenefit comparison of materials, etc.).

\subsection{Understanding the Risks}

The number of individuals in the education industry who correctly understand risk management is not large. Because the concept of risk is not understood well, the number of teachers who practice risk management consciously is probably small. However, just because these individuals do not know the term "risk management," it does not mean that certain risk management practices are not seen. Traditionally, for instance, the experience and intuition of the teacher had a great significance as a method of risk management.

However, in terms of scale, career education projects that were once participated in by only a small number of students are now becoming events participated in by entire schools. In such cases, it is difficult to effectively follow through on a program relying only on teachers' experience and intuition because, under a project model in Table 2, it is necessary to understand systematic risk management and how to respond to issues that might arise.

This being the case, how do teachers perceive risks at school? There are not many teachers who can clearly answer what a risk is in career education; most of them merely recognize a risk as anything that could disrupt the smooth completion of the program. In other words, they can easily end up not knowing what measures to take and wasting time when there is a risk, because they are not diagnosing it correctly.

For effective risk management, it is necessary to correctly recognize the risk itself (its presence and nature). For example, what risks emerge in internships?

Many schools arrange internships for their students, making them a popular method to support students' autonomous growth. However, the current state of internship arrangements in Japan continues to involve trial and error, and there are not many cases where cooperation among schools, companies, and local communities is implemented organically on an ongoing basis. In general, it is difficult to keep up a project that overstretches itself at the initial stage, that is, one that exhausts the school's ability to follow up on the educational goals. In recent years, MEXT has set various requirements related to the introduction of career education and reporting of its results, and schools may be increasingly taxed.

The skill set of a teacher is quite different than that required to operate a joint career education project with a business organization. Yet teachers often take on projects such as an internship without understanding that difference and without adequate support, and thus are sometimes forced to make significant changes to the project plan because some resource or reporting requirement is unsustainable. In short, the reality is that schools often rely on teachers to manage the progress of projects and assess the quality of education achieved. In many cases, risk countermeasures are implemented by teachers based on their class experience and are not effective in an office context. Their response to risk tends to be slow, because many of the risks they face are new experiences for them.

In order to deal with these issues, it is necessary to understand the nature of the risk itself in order to design proper countermeasures, and thus to have a project manager with experience in the business world. In this sense, it can be considered that lack of understanding of the importance of a project manager is the largest risk inherent in career education.

So how can we finally define "risk management" in the context of career education? Aiming to operate a career education program without generating risk is a matter of quality control; thus, it is outside of the scope of risk management. In other words, risk management is not the management of the occurrence of risk; it is the prediction of the risks of possible events by multiplying risk probability by the severity of possible risk outcomes and the effort to keep the figure obtained below a certain level. 
Table 2. The flow of a career education program based on the PMBOK management system.

\begin{tabular}{|c|c|c|c|c|c|}
\hline \multirow{2}{*}{$\begin{array}{c}\text { Knowledge-related } \\
\text { processes }\end{array}$} & \multicolumn{5}{|c|}{ Project management process groups } \\
\hline & $\begin{array}{l}\text { Launching } \\
\text { processes }\end{array}$ & $\begin{array}{l}\text { Planning } \\
\text { processes }\end{array}$ & $\begin{array}{l}\text { Execution } \\
\text { processes }\end{array}$ & $\begin{array}{c}\text { Monitoring/supervising } \\
\text { processes }\end{array}$ & $\begin{array}{l}\text { Ending } \\
\text { processes }\end{array}$ \\
\hline $\begin{array}{c}\text { Scope } \\
\text { management }\end{array}$ & $\begin{array}{l}\text { 1) Determine the } \\
\text { number of work-hours } \\
\text { to commit }\end{array}$ & $\begin{array}{l}\text { 1) Define the scope } \\
\text { of the project } \\
\text { 2) Prepare a WBS }\end{array}$ & $\begin{array}{l}\text { 1) Execute the } \\
\text { plan and manage } \\
\text { the process }\end{array}$ & $\begin{array}{l}\text { 1) Assess the scope } \\
\text { of the project } \\
\text { 2) Manage the scope }\end{array}$ & $\begin{array}{l}\text { 1) Manage the } \\
\text { ending process }\end{array}$ \\
\hline Time management & $\begin{array}{l}\text { 1) Draft a schedule } \\
\text { 2) Create a detailed } \\
\text { timetable for the } \\
\text { launch day }\end{array}$ & $\begin{array}{l}\text { 1) Define activities } \\
\text { 2) Determine the } \\
\text { order of activities } \\
\text { 3) Estimate resources } \\
\text { needed }\end{array}$ & $\begin{array}{l}\text { 1) Consider the } \\
\text { relationship between } \\
\text { project scope and } \\
\text { time allotted }\end{array}$ & $\begin{array}{l}\text { 1) Manage the } \\
\text { schedule }\end{array}$ & $\begin{array}{l}\text { 1) Determine } \\
\text { whether a time } \\
\text { extension is } \\
\text { necessary }\end{array}$ \\
\hline Cost management & $\begin{array}{l}\text { 1) Estimate the cost } \\
\text { for the entire plan }\end{array}$ & 1) Budget the cost & $\begin{array}{l}\text { 1) Assess the budget } \\
\text { constraints in } \\
\text { executing the } \\
\text { project }\end{array}$ & 1) Control cost & $\begin{array}{l}\text { 1) Return unnecessary } \\
\text { resources } \\
\text { 2) Handle budget } \\
\text { overrun }\end{array}$ \\
\hline $\begin{array}{c}\text { Quality } \\
\text { management }\end{array}$ & $\begin{array}{l}\text { 1) Maintain quality } \\
\text { at startup }\end{array}$ & $\begin{array}{l}\text { 1) Prepare an overall } \\
\text { quality plan }\end{array}$ & $\begin{array}{l}\text { 1) Provide quality } \\
\text { assurance }\end{array}$ & 1) Control quality & $\begin{array}{l}\text { 1) Continue to } \\
\text { maintain and } \\
\text { improve quality }\end{array}$ \\
\hline $\begin{array}{l}\text { Human resources } \\
\text { management }\end{array}$ & $\begin{array}{l}\text { 1) Organize a team } \\
\text { with all needed } \\
\text { personnel }\end{array}$ & $\begin{array}{l}\text { 1) Make a human } \\
\text { resources plan }\end{array}$ & $\begin{array}{l}\text { 1) Manage skills } \\
\text { 2) Secure needed } \\
\text { personnel }\end{array}$ & $\begin{array}{l}\text { 1) Create a phone tree } \\
\text { among teachers and } \\
\text { companies }\end{array}$ & $\begin{array}{l}\text { 1) Review the } \\
\text { activities }\end{array}$ \\
\hline $\begin{array}{l}\text { Communication } \\
\text { management }\end{array}$ & $\begin{array}{l}\text { 1) Verify backgrounds } \\
\text { 2) Determine the means } \\
\text { of communication }\end{array}$ & $\begin{array}{l}\text { 1) Make a } \\
\text { communicaton } \\
\text { plan }\end{array}$ & $\begin{array}{l}\text { 1) Verify } \\
\text { communication skills } \\
\text { 2) Engage proactively } \\
\text { in communication }\end{array}$ & $\begin{array}{l}\text { 1) Establish a } \\
\text { comprehensive } \\
\text { system for reporting } \\
\text { events }\end{array}$ & $\begin{array}{l}\text { 1) Check activity } \\
\text { report meetings } \\
\text { and event lists }\end{array}$ \\
\hline Risk management & $\begin{array}{l}\text { 1) Discern which } \\
\text { risks are acceptable } \\
\text { 2) Create a list of how } \\
\text { to handle risks } \\
\text { when they occur } \\
\text { 3) Itemize expected risks }\end{array}$ & $\begin{array}{l}\text { 1) Make a plan for } \\
\text { risk management } \\
\text { 2) Identify risks } \\
\text { 3) Make a plan for } \\
\text { handling the risks }\end{array}$ & $\begin{array}{l}\text { 1) Check readiness } \\
\text { for expected risks } \\
\text { 2) Make a } \\
\text { contingency plan }\end{array}$ & $\begin{array}{l}\text { 1) Identify } \\
\text { uncontrollable events } \\
\text { 2) Manage children's } \\
\text { mental aspects }\end{array}$ & $\begin{array}{l}\text { 1) Balance the } \\
\text { risk and return } \\
\text { for each event }\end{array}$ \\
\hline $\begin{array}{l}\text { Procurement } \\
\text { management }\end{array}$ & $\begin{array}{l}\text { 1) Consider needs } \\
\text { in procuring items } \\
\text { 2) Identify items } \\
\text { that can/cannot } \\
\text { be purchased }\end{array}$ & $\begin{array}{l}\text { 1) Make a plan for } \\
\text { purchasing/acquisition } \\
\text { of materials } \\
2 \text { Make a plan for } \\
\text { contracts }\end{array}$ & $\begin{array}{l}\text { 1) Submit a request } \\
\text { for procurement } \\
\text { (RFP) to suppliers } \\
\text { 2) Select a supplier }\end{array}$ & $\begin{array}{l}\text { 1) Manage the } \\
\text { contract }\end{array}$ & $\begin{array}{l}\text { 1) Terminate the } \\
\text { contract }\end{array}$ \\
\hline
\end{tabular}

Source: Adapted from A Guide to the Project Management Body of Knowledge, 3rd edition.

What should be noted here is that the obtained figure is not necessarily negative. By nature, risks have both positive and negative implications. Risks should be recognized as aggregates of positives and negatives. (Incidentally, it should be noted that cases that will certainly occur ought not to be considered risks, but rather definite future events.)

Avoiding the risks that lead to loss while accepting, pursuing, and maximizing positive-risk figures-that is, the risks that lead to opportunities-are important considerations in career education projects.

Companies generally monitor interns closely and evaluate their progress and understanding of the business. In that process, it is necessary to minimize negative risks such as lack of productivity by the student, for example due to overwhelm. Conversely, if the student is highly adaptable, it is important for the company to recognize the potential to take a positive risk on the student, for example by hiring him or her in a permanent position later on.

In other words, a career education project consists of consecutive opportunities and losses due to risk, which must be faced by each student. The smooth operation of the program and the success of the project should be planned and executed in a way that consciously expands the opportunities rather than just controlling the losses. 


\subsection{Proactive Risk Management}

Proactive risk management is management that identifies the occurrence of risk proactively and takes the initiative quickly by taking action in advance. To do so, it is important to take a stance from which one can purposely choose risks that have to be taken or are advantageous while avoiding unnecessary or disadvantageous risks. With that type of decision-making in mind as a goal, one needs above all to forecast risk and act prior to its occurrence.

Proactive risk management is required in career education, for example as students' workplace behavior changes during their internship. That is, once students become familiar with the company as a place of work and settle into their role, their attitude frequently becomes less alert. Some students may keep coming in late or skipping work without calling in. Proactive risk management of a career education project is not just about warning the student not to fall prey to these tendencies; it is also important to have available the option of terminating the student's training, depending on the situation. Since internships are educational in focus, the risks of students' actions are sometimes underestimated from a perspective in which the most important thing is the student's learning; however, from the standpoint of project management, it appears that proactive risk assessment needs to take the worst-case scenario into consideration. In this sense, the presence of a project manager who can make professional judgments of this sort correctly is essential in implementing a career education project.

The effective implementation and management of a career education program depends on the ability of the project manager to identify and control risk appropriately. Career education is more than just a service provided to students. It is a broader endeavor, one entailing a need to consider the viewpoints of all involved and grasp their respective needs.

What this means is that one of the most important skills for successful risk management in the field of career education is the ability to facilitate communication between the parties involved. This is what makes a project manager effective for risk management. There are plenty of risks to consider: for example, a student could get injured during an internship, or a student could be exposed to various forms of harassment in a corporate environment. Even incorrect scheduling or poor communication about issues such as working hours can cause students to encounter physical and emotional risks.

It is hard to overemphasize the importance of a project manager's risk management capabilities in adequately addressing such situations. Indeed, it can be said that the success or failure of the career education project rests on the ability of the project manager to skillfully identify and control the various risks presented by the project.

\section{Conclusion}

Although career education activities are done as part of school classes, they are nevertheless projects intended to be completed in a defined period of time. With the aim of developing students' understanding of the work world, these projects allow students to experience work in a limited capacity with the cooperation of the companies or public agencies in which they are placed. The introduction and implementation of career education is currently considered a pressing issue for Japanese schools ranging from elementary schools to universities, and an extensive process of trial and error is underway. It is becoming apparent that there are various resource shortages within schools that impact career education projects, such as issues of funding and placements for students. Among these issues, however, the most serious is the shortage of personnel who can properly run a project. Many teachers are currently wrestling with career education projects in the unfamiliar role of administrators; however, circumstances such as their busy schedules and lack of experience are hampering the implementation of effective career education.

The successful implementation of a career education project comes down to the ability of the project manager to minimize risk while maximizing return. That is, the success or failure of this project rests on the risk management proficiency of its manager. In this sense, the key to success in career education goes well beyond what we can ask of teachers alone, although there are times, of course, when we can provide them with specialized training to cultivate their skills, just as there are times when we can bring in talented individuals from the outside world. In either case, it is important that we do what is necessary to develop skilled career education managers.

As a framework to cultivate career view of young people and enhance their voluntary career formation, career education has been introduced and practiced in each school from elementary schools to universities. Since choice of implementation methods of career education with its diverse contents is in the hands of each teacher in 
the current setting, career education which should be implemented in organizational and continuous manner by keeping specific quality has not functioned well in reality resulting in various evident risks observed. This paper verified that an introduction of project manager to career education which has been implemented by each teacher on his or her own discretion is effective for risk management on career education management by focusing on a notion that career education itself is a project.

This paper has made an original contribution by clarifying the effectiveness of the use of a project manager in career education and suggesting that such managers be introduced into career education for risk management reasons. However, a project manager can also prove him- or herself very useful in the areas of quality management and communication management, in particular in coordinating actions among the company, school, student, teacher, and stakeholders in the local community. Thus, in the future, it will probably be necessary to more thoroughly examine the effectiveness of the use of a project manager in career education in terms of communication management.

\section{References}

Benesse Educational Research and Development Center (2008). The Realities of Academic Guidance and the Awareness of Teachers in Elementary and Junior High Schools. Tokyo: Benesse. (In Japanese)

Central Council for Education (1999). Improving the Connection between Elementary/Secondary Education and Higher Education (a Report). Tokyo: Japanese Ministry of Education, Culture, Sports, Science and Technology. (In Japanese)

Central Council for Education (2011). The Way Career Education and Vocational Education Should Be in the School in the Future (a Report). Tokyo: Japanese Ministry of Education, Culture, Sports, Science and Technology. (In Japanese)

Council of Collaborators Conducting Comprehensive Research on Career Education Promotion (2004). To Develop Each Student's View on Work and Occupations. Tokyo: Japanese Ministry of Education, Culture, Sports, Science and Technology. (In Japanese)

Hayashi, T. (2011). The Development of Teachers Training Model and Web-Based Material for Communication Skill. The Journal of Japan Society of Educational Information, 26, 3-15.

Kitagami, M., \& Takagi, R. (2007). Japanese Teachers’ Busyness and Recognition of Official Busyness I. Bulletin of Graduate School of Education, Okayama University, 134, 1-10.

Shintani, Y. (2012). Business of Teachers and the Nature of Work: Based on Observational Studies. Public Education System Studies, 11, 1-36. (In Japanese) 